\title{
Effect of Open and Closed Operation Modes on the Performance of Phase Change Material Based Copper Heat Exchanger
}

\author{
Saulius Pakalka ${ }^{1 *}$, Kęstutis Valančius ${ }^{2}$, Matas Damonskis ${ }^{3}$ \\ ${ }^{1,2}$ Department of Building Energetics, Vilnius Gediminas Technical University, Vilnius, Lithuania \\ ${ }^{1,3}$ Applied Research Institute for Prospective Technologies, Vilnius, Lithuania
}

Received 24 February 2020; accepted 17 March 2020

\begin{abstract}
Many studies related to latent heat thermal energy storage (LHTES) and performance of phase change materials (PCM) are focused on melting and solidification processes. Investigating and understanding the influence of various parameters on PCMs based thermal energy storage is the key to developing innovative and efficient energy storage systems. The aim of this study is to experimentally compare and assess the performance of phase change material based copper heat exchanger (PCM-HX) in different modes of operation. This PCM-HX is designed to be used in systems where thermal energy can be stored up to $90{ }^{\circ} \mathrm{C}$ and an organic PCM RT82 was selected as the energy storage medium. This study focuses on the pressure impact on the PCM melting (charging) and solidification (discharging) processes. Two different modes of operation were analysed: Open and Closed. In the case of an Open mode, the storage tank of PCM-HX was open to the atmosphere (pressure control valve open), in the case of Closed mode the storage tank was closed (pressure control valve closed). PCM charging and discharging processes were conducted and the PCM-HX performances were tested at different pressure inside the storage tank.
\end{abstract}

Keywords: heat exchanger, Phase change material (PCM), melting and solidification, latent heat thermal energy storage performance, operation mode.

\section{Introduction}

Latent heat thermal energy storage plays an important role in increasing the energy density of the storage systems. For latent heat storage, different types of phase change materials (PCMs) can be used. However, one of the main tasks in developing PCM based thermal energy storage systems (PCM-TES) is the assurance of an effective heat exchange process because of the low thermal conductivity of most PCMs. Heat exchange process parameters can be characterized by using computer modelling and obtained results can be used for device or system optimization. Moreover, many studies focus on the experimental investigation of different technical solutions in order to enhance melting and solidification time of the PCM. It was observed that impregnation of heat conduction matrices (such as aluminium, copper, graphite) (Martinelli et al., 2016; Li et al., 2017; Merlin et al., 2016; Righetti et al., 2019) or enlargement of heat exchange surface area (Z. Khan \& Z. A. Khan 2017; Kabbara et al., 2016; Besagni \& Croci, 2019) have been found to be very useful in terms of heat transfer rate improvement.

Furthermore, the density change or volume and pressure variations of PCM during phase transition can also affect the performance of the PCM-TES. These parameters should be addressed during the design process of such devices and systems. Several studies have already been conducted to investigate how density change influences the characteristics of PCM-TES. For example, Peng et al. (2019) analysed impacts of thermal conductivity and density of PCM on the characteristics of PCM-based thermal energy storage systems. Cabeza, Zsembinszki, and Martín investigated in the laboratory and at the pilot plant scale the volume variations of different PCMs due to the density difference between the solid and liquid phases. Janghel et al. (2019) developed a one-dimensional semi-analytical model for the finite domain of air-PCM systems to analyse the formation of void during the solidification shrinkage. Hernández-Cooper, Otero investigated the effects of pressure-induced density changes in the thermal energy absorbed by the PCM. Dallaire, Gosselin classified different methods of accommodating density variation during solid-liquid phase change and derived two new models of thermo-mechanical coupling between the PCM and its container. Chiew et al. (2017) performed numerical and experimental research of the effect of the air void space on the heat transfer within a cylindrical enclosure. Chiew et al. (2019) developed macro-encapsulated PCM enclosure with a dampening

*Corresponding author. E-mail: saulius.pakalka@vgtu.lt

Copyright (C) 2020 The Author(s). Published by VGTU Press

This is an Open Access article distributed under the terms of the Creative Commons Attribution License (http://creativecommons.org/licenses/by/4.0/), which permits unrestricted use, distribution, and reproduction in any medium, provided the original author and source are credited. 
assembly that maximizes thermal contact and eliminates void space formed during shrinkage of the PCM during solidification.

The aim of this study is to experimentally compare and assess the performance of phase change material (PCM) based copper heat exchanger (PCM-HX) when the density of PCM and pressure inside storage tank changes during melting (charging) and solidification (discharging). PCM-HX is a small scale prototype of thermal energy storage which consists of an insulated stainless steel tank (pressure vessel) with fin-and-tube type copper heat exchanger. PCM-HX is specially designed for use with industrial waste heat recovery systems, e.g. with residual steam up to $100{ }^{\circ} \mathrm{C}$. For thermal energy storage, an organic PCM RT82 (produced by Rubitherm Technologies GmbH) was selected. The storage tank was filled (75\%) with solid PCM leaving an air gap to accommodate the expansion during melting. During the phase change process, the density of PCM changes and it causes volume variation inside the storage tank. This volume variation leads to an increase of liquid PCM level in the tank during melting and to the formation of gaps and voids between heat transfer surfaces during the solidification (shrinkage of solid-phase). Volume expansion due to the density change increases the air pressure inside the closed tank (internal pressure) and compressed air acts like constraint for the expansion itself (opposite force against expansion). In order to evaluate the influence of increased air pressure two different modes of operation were analysed: Open and Closed. In the case of an Open mode, the storage tank of PCM-HX was open to the atmosphere (pressure control valve open), in the case of Closed mode the storage tank was closed (pressure control valve closed).

This experimental investigation complements the previous research on possibilities to use PCM in heat exchangers-accumulators, simulation of PCM characteristics in thermal energy storage and investigation of the influence of mass flow rate on PCM behaviour (Pakalka et al., 2017, 2018, 2019).

\section{Experimental setup and procedure}

The experimental setup employed in the present study is the same as that used in our previous study (Pakalka et al., 2019). Additionally, PCM-HX was equipped with a manual pressure control valve (vent valve) and a pressure sensor. Schematic representation of the experimental setup (test bench) is shown in Figure 1.

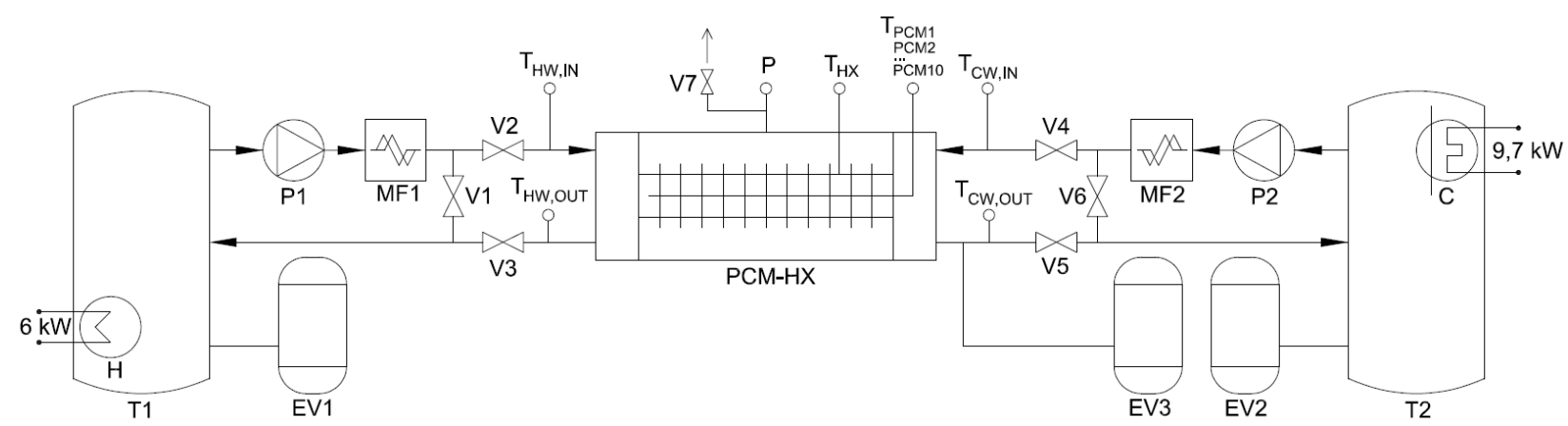

Figure 1. Schematic representation of the experimental setup

Figure 1 shows a schematic drawing of the experimental setup, which consists of PCM based thermal energy storage device with copper HX (PCM-HX), two separate fluid loops of cold and hot water for PCM melting (charging) and solidification (discharging) respectively and measurement instruments. PCM-HX and PCM RT82 parameters are presented in Table 1. Both loops consist of $300 \mathrm{~L}$ isolated tanks for water storage (T1, T2), expansion vessels (EV1EV3), heater $(\mathrm{H})$ and cooler $(\mathrm{C})$ for hot and cold water preparation respectively, valves (V1-V6), mass flowmeters (MF1, MF2) and circulating pumps (P1, P2) for water flow control.

The experimental setup has two separate loops for hot and cold water, which allows to interchangeably perform full cycles of PCM melting (charging) and solidification (discharging). Experiments for this study were carried out using $0.2 \mathrm{~kg} / \mathrm{s}$ water mass flowrate. At the beginning of the melting cycle, PCM is in the solid phase at the initial temperature of $30{ }^{\circ} \mathrm{C}$. Hot water loop is opened while cold is closed and hot water circulates through HX and heat exchange occurs resulting in the phase change of PCM from solid to liquid at the temperature interval $77-82{ }^{\circ} \mathrm{C}$. The melting cycle ends when all PCM is in the liquid phase. Analogically, at the beginning of the solidification cycle, PCM is in the liquid phase at the initial temperature of $90{ }^{\circ} \mathrm{C}$. Cold water loop is opened while hot is closed and cold water circulates through HX and the phase change of the PCM in reverse order begins. The solidification cycle ends when the temperature of the PCM becomes close to the temperature of the cold water.

The temperature of HX $\left(\mathrm{T}_{\mathrm{HX}}\right), \mathrm{PCM}\left(\mathrm{T}_{\mathrm{PCM} 1}-\mathrm{T}_{\mathrm{PCM} 10}\right)$, hot and cold water inlet $\left(\mathrm{T}_{\mathrm{HW}, \mathrm{IN}}, \mathrm{T}_{\mathrm{CW}, \mathrm{IN}}\right)$ and outlet $\left(\mathrm{T}_{\mathrm{HW}, \mathrm{OUT}}\right.$, $\mathrm{T}_{\mathrm{CW}, \mathrm{OUT}}$ ) was measured with PT100 temperature sensors (class $\mathrm{B}$, accuracy $\pm(0.3+0.005 \times \mathrm{t}){ }^{\circ} \mathrm{C}$ ) (see Figure $2 \mathrm{~b}$ ). Temperature sensors $\mathrm{T}_{\mathrm{PCM} 1, \mathrm{PCM} 4, \mathrm{PCM} 6 \text {,PCM9, }} \mathrm{T}_{\mathrm{PCM} 2, \mathrm{PCM} 5 \text {,PCM7,PCM10 }}$ and $\mathrm{T}_{\mathrm{PCM} 3, \mathrm{PCM} 9}$ were in the PCM at the distance 14, 24 and $30 \mathrm{~mm}$ from the front side wall of PCM-HX storage tank. Pressure in the storage tank of PCM-HX was measured by pressure sensor $\mathrm{P}$ (accuracy $\pm 0.5 \%$ ) and controlled during the experiment with pressure control valve V7 (see 
Figure 2a). The water mass flow rate was measured with flowmeters (MF1, MF2) (accuracy $\pm 0.15 \%$ ). All parameters of the measurement were monitored in real-time and collected in the control system.

The heat flux $\left(\mathrm{W} / \mathrm{m}^{2}\right)$ is calculated by using the general formula (1):

$$
q=\frac{\dot{Q}}{A}=\frac{\dot{m} c_{p} d T}{A}
$$

where: $\dot{m}$ is the mass flow rate of the heat transfer fluid, $\mathrm{kg} / \mathrm{s} ; c_{p}$ is the specific heat capacity at constant pressure, $\mathrm{J} /(\mathrm{kg} \cdot \mathrm{K}) ; d T$ - temperature difference, $\mathrm{K} ; A$ - heat transfer area, $\mathrm{m}^{2}$.

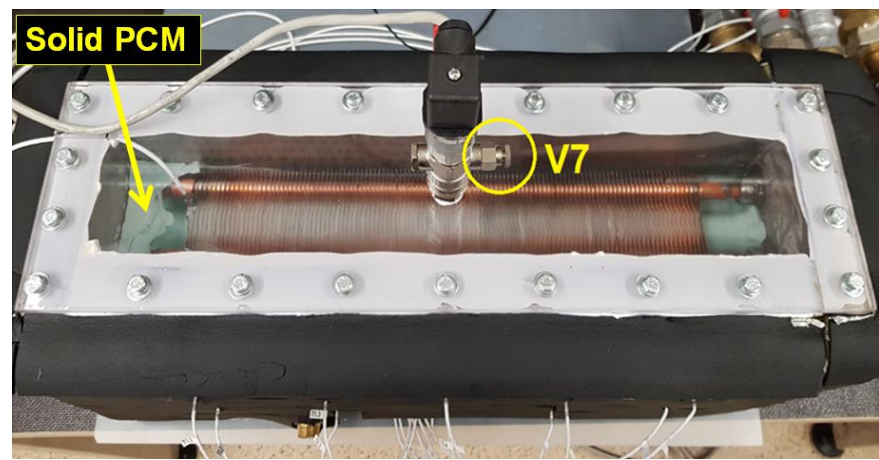

a)

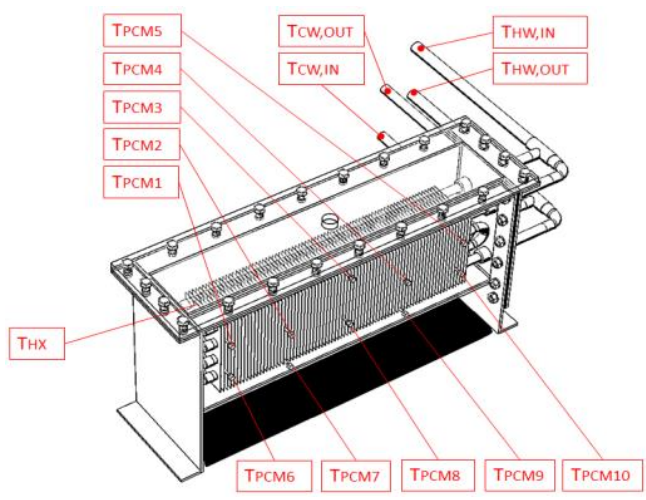

b)

Figure 2. a) PCM heat exchanger ready for the experiment (V7 - valve for pressure control);

b) scheme of PCM-HX with temperature sensor positions

Table 1. Parameters of analysed PCM based heat storage unit

\begin{tabular}{|l|c|l|c|}
\hline \multicolumn{2}{|c|}{ PCM heat exchanger } & \multicolumn{2}{c|}{ Properties of PCM Rubitherm RT82 } \\
\hline Fin quantity, units & 79 & Melting area, ${ }^{\circ} \mathrm{C}$ & $77-82$ \\
\hline Fin spacing, mm & 5 & Congealing area, ${ }^{\circ} \mathrm{C}$ & $82-77$ \\
\hline Fin thickness, mm & 0.15 & Heat storage capacity $( \pm 7.5 \%), \mathrm{kJ} / \mathrm{kg}$ & 170 \\
\hline Tube diameter $(\mathrm{OD}), \mathrm{mm}$ & 12.7 & Specific heat capacity, $\mathrm{kJ} / \mathrm{kgK}$ & 2 \\
\hline Tube thickness, mm & 0.5 & Density solid at $15{ }^{\circ} \mathrm{C}, \mathrm{kg} / \mathrm{L}$ & 0.88 \\
\hline Heat exchanger weight, $\mathrm{kg}$ & 2.1 & Density liquid at $90{ }^{\circ} \mathrm{C}, \mathrm{kg} / \mathrm{L}$ & 0.77 \\
\hline HX heat transfer area, $\mathrm{m}^{2}$ & 1.75 & Heat conductivity $($ both $\mathrm{phases}), \mathrm{W} / \mathrm{mK}$ & 0.2 \\
\hline PCM weight, $\mathrm{kg}$ & 4.34 & Volume expansion, $\%$ & 12.5 \\
\hline PCM volume solid/liquid, $\mathrm{L}$ & $4.93 / 5.64$ & Max operation temperature, ${ }^{\circ} \mathrm{C}$ & 100 \\
\hline
\end{tabular}

\section{Results and discussion}

During the experiment, internal pressure change inside the closed storage tank (PCM-HX) was monitored (see Figure 3). It should be noted that in the case of the charging process the pressure increase was measured from the initial PCM temperature of $30^{\circ} \mathrm{C}$ to the final average temperature of $90^{\circ} \mathrm{C}$. In the case of the discharging process, pressure decrease was measured from the initial temperature of $90{ }^{\circ} \mathrm{C}$ to the final average temperature of $30{ }^{\circ} \mathrm{C}$. It means pressure increase/decrease was caused not only by phase change but also by thermal expansion of PCM below and above the melting point. In the case of the Open mode of operation, a pressure control valve was open to the atmosphere and no pressure change has been observed inside the storage tank.

Figure 3 shows monitoring data of internal pressure increase during Closed operating mode. The pressure variation occurs in the closed tank due to thermal expansion (density change) of PCM and air. First of all, PCM expands during the heating up from a certain temperature to the melting point. Then thermal expansion takes place during solid to liquid phase transition (melting), and finally PCM expands during heating up from melting point to a certain temperature. An air gap, which is between the PCM and the top wall is compressed and gives more space to the PCM for expansion. Nevertheless, already compressed air inside the storage tank also expands at elevated temperatures and all volumetric expansions cause an increase in internal pressure. 


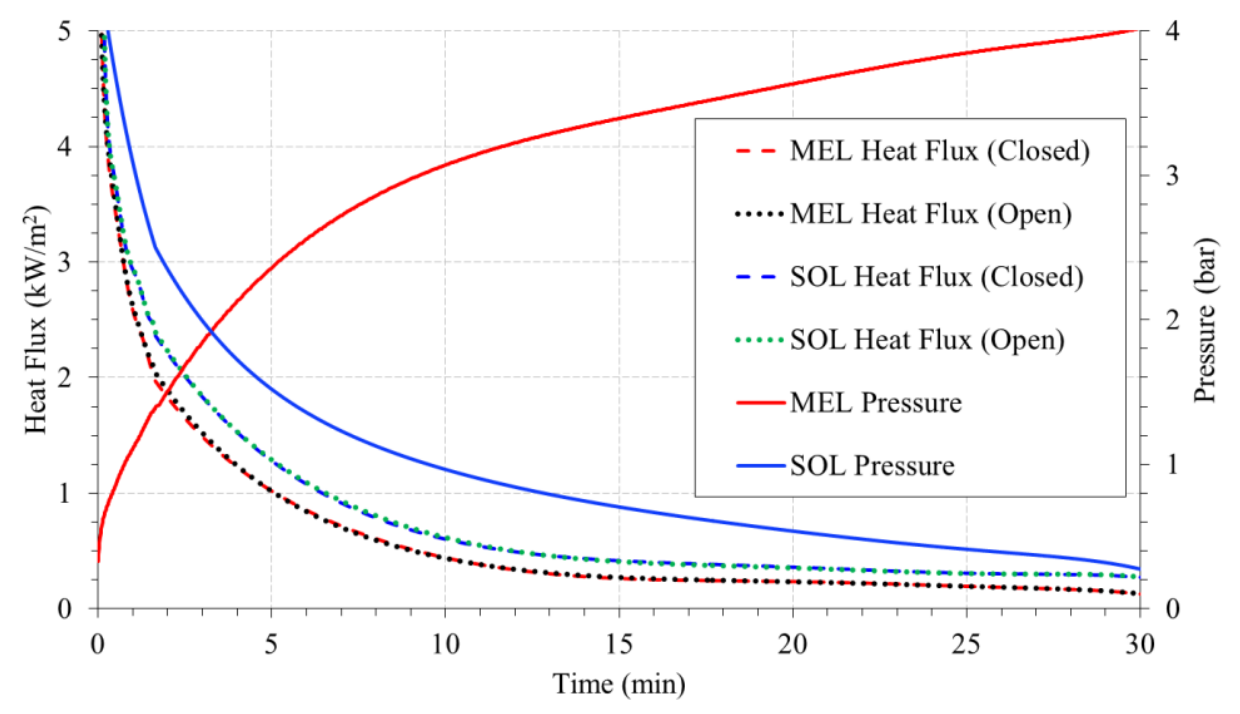

Figure 3. PCM-HX internal pressure and heat flux (MEL - melting; SOL - solidification)

As can be seen in Figure 3, during 30 minutes of melting process pressure increases from 0.3 bar up to 4.0 bar, and during $30 \mathrm{~min}$ of solidification process pressure decreases from 4.0 bar to 0.3 bar. In both cases, the pressure difference is 3.7 bar. It should be noticed that before starting of melting process PCM was already preheated to $30{ }^{\circ} \mathrm{C}$ and this is the reason why pressure at the beginning was 0.3 bar.

During the melting and solidification processes, the heat flux in Open mode differs very slightly from Closed mode and on average it is higher no more than $1 \%$ (see Figure 3). In both modes, higher heat flux is observed during the solidification because of the higher temperature difference between inlet cold water and PCM average temperature.

The change in the surface temperature of the heat exchanger $\left(\mathrm{T}_{\mathrm{HX}}\right)$ during the melting and solidification process, the average temperature of the PCM ( $\left.\mathrm{T}_{\mathrm{PCM}, \mathrm{AVG}}\right)$, the temperature of inlet and outlet fluids $\left(\mathrm{T}_{\mathrm{HW}, \mathrm{IN}}, \mathrm{T}_{\mathrm{HW}, \mathrm{OUT}}\right)$ and the temperature difference between inlet and outlet fluids $(\Delta \mathrm{T})$ are shown in Figure 4 and 5 . At the start of the melting process, the heat exchanger contains a PCM that is in its solid phase, the initial temperature of $30^{\circ} \mathrm{C}$. At the start of the solidification process, the heat exchanger contains a PCM that is in its liquid phase, the initial temperature of $90{ }^{\circ} \mathrm{C}$.

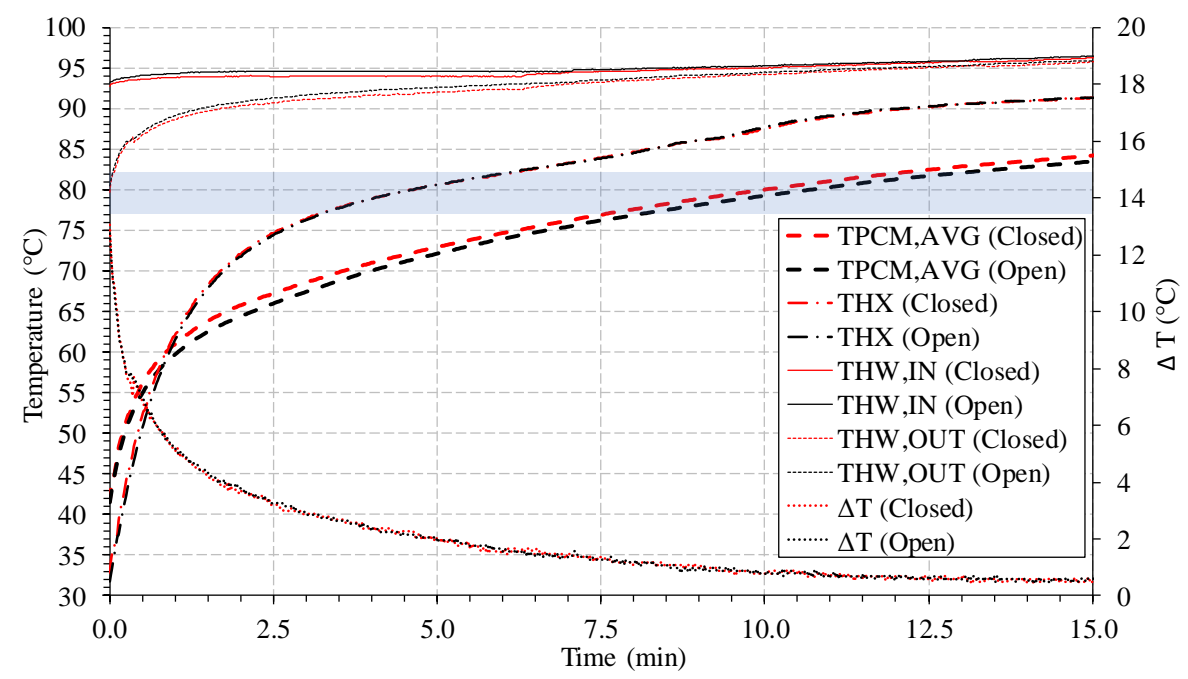

Figure 4. Melting (charging) process in Open and Closed mode

Figure 4 shows that at the beginning of the melting process, in the case of the Closed mode of operation inlet and outlet temperatures of water are slightly lower (on average about $0.5^{\circ} \mathrm{C}$ ) compared with the Open system. After $6.5 \mathrm{~min}$ the difference of these temperatures decreases to $0.2^{\circ} \mathrm{C}$. The temperature difference between inlet and outlet fluids $(\Delta \mathrm{T})$ decreases depending on the temperature of the PCM but remains the same in both modes of operation. At the beginning of the melting process, there is a sudden increase in the surface temperature of heat exchanger $\mathrm{T}_{\mathrm{HX}}$ in both modes of operation (Open and Closed). The temperature difference between heat exchanger $\mathrm{T}_{\mathrm{Hx}}$ and inlet hot water $\mathrm{T}_{\mathrm{HW}, \mathrm{IN}}$ decreases. After $3 \mathrm{~min}$ from the beginning of the melting process, the surface temperature of the heat exchanger 
reaches the melting temperature of the $\mathrm{PCM}\left(77^{\circ} \mathrm{C}\right)$ and after 12 min reaches $90{ }^{\circ} \mathrm{C}$. From this point temperature difference between heat exchanger $\mathrm{T}_{\mathrm{HX}}$ and inlet hot water $\mathrm{T}_{\mathrm{HW}, \mathrm{IN}}$ remains constant about $5^{\circ} \mathrm{C}$. Following the average temperature of the PCM, it can be seen that the average duration of the phase change (from $77^{\circ} \mathrm{C}$ to $82{ }^{\circ} \mathrm{C}$ ) is 4.4 min in the case of the Closed system and $4.8 \mathrm{~min}$ in the case of the Open system. Even though in the case of the Closed system the average temperature of inlet water during phase change interval is $0.2^{\circ} \mathrm{C}$ lower the duration of phase change is 0.4 min shorter compared with the Open system (4.4 min vs. 4.8 min respectively).

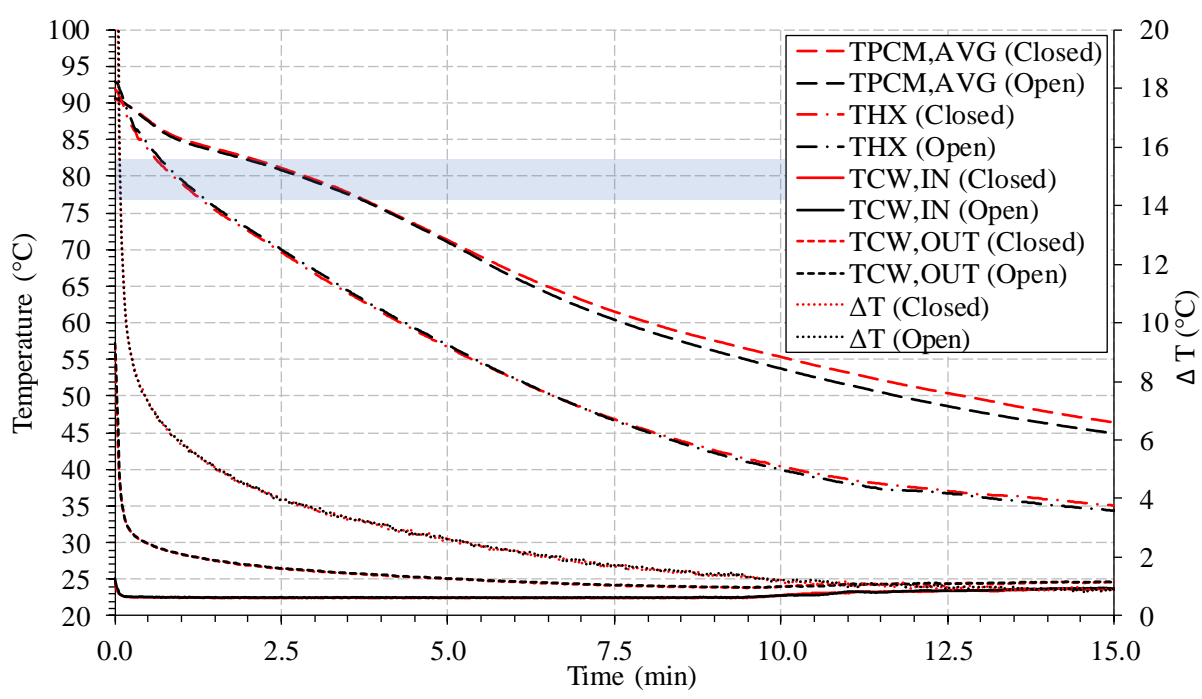

Figure 5. Solidification (discharging) process in Open and Closed mode

Figure 5 shows that at the beginning of the solidification process, in both cases of the mode of operation inlet and outlet temperatures of water are equal. The temperature difference between inlet and outlet fluids $(\Delta \mathrm{T})$ decreases depending on the temperature of the PCM and remains the same in both modes of operation. At the beginning of the solidification process, there is a sudden decrease in the surface temperature of heat exchanger $\mathrm{T}_{\mathrm{HX}}$ in both modes of operation (Open and Closed). The temperature difference between heat exchanger $\mathrm{T}_{\mathrm{HX}}$ and inlet cold water $\mathrm{T}_{\mathrm{CW}, \mathrm{IN}}$ decreases. After $1.5 \mathrm{~min}$ from the beginning of the solidification process, the surface temperature of the heat exchanger reaches the solidification temperature of the PCM $\left(77^{\circ} \mathrm{C}\right)$. Following the average temperature of the PCM, it can be seen that the average duration of the phase change is $1.5 \mathrm{~min}$ in the case of the Closed system and $1.6 \mathrm{~min}$ in the case of the Open system. During the solidification, the temperature of inlet water in both modes of operation is the same.

It should be noticed that $\mathrm{T}_{\mathrm{AVG}}$ shows an average temperature of 10 temperature sensors located in different positions in the heat exchanger and does not show full melting/solidification time. In order to evaluate phase change durations in more detail, different measurement points should be analysed. Temperature distribution between different measurement points and phase change duration in each point is shown in Figure 6a), b) and e) (melting process) and Figure $6 \mathrm{c}$ ), d) and f) (solidification process). In this analysis phase change duration means time interval from initial melting temperature $77^{\circ} \mathrm{C}$ to final melting temperature $82^{\circ} \mathrm{C}$.

The phase change process is not uniform in all of the PCM volume, and some measuring points show slightly different values when two experiments are compared. But looking integrally at the PCM (on average of the phase change duration) overall conclusions on the system and its modes can be made. Figure 6 shows that PCM reaches the melting (a) and b)) and solidification (c) and d)) temperature in different measurement points at different times. From the Figure 6e) it can be seen that phase change duration during the melting is longer in the case of Closed mode in the points TPCM2, TPCM3, TPCM4 and TPCM5. Despite the longer phase transition in these points in the Closed mode, on average the melting process was 0.15 min or $3.2 \%$ longer in Open mode. Figure 6f) shows that phase change duration during solidification is longer in the case of Closed mode in the points TPCM 2 and TPCM4. However, on average the solidification process was 0.03 min or $1.7 \%$ longer in Open mode. Even though the phase change durations in different measurement points differs very slightly between Closed and Open modes, the analysis demonstrates that operating under a certain pressure can improve the PCM melting and solidification time. 


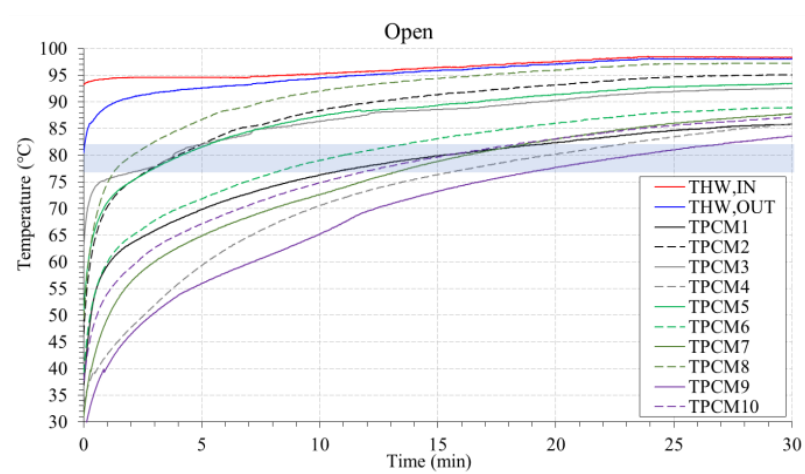

a)

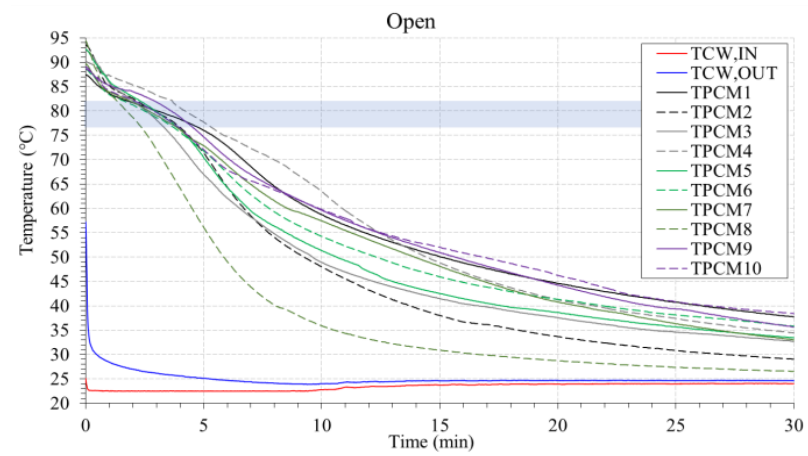

c)

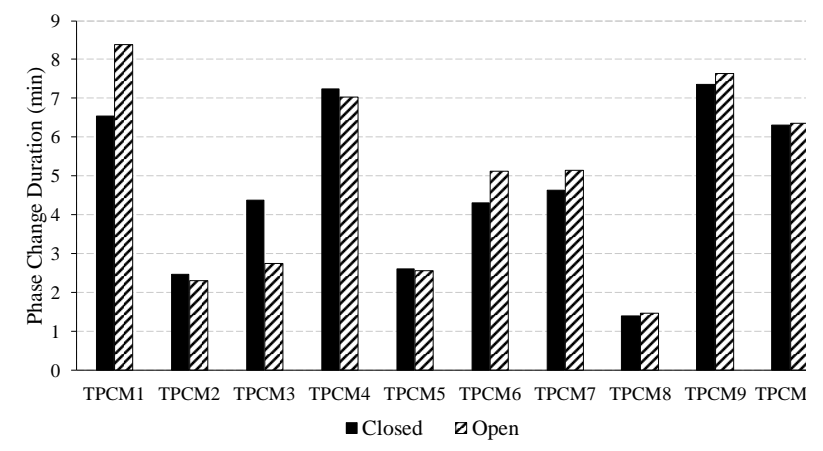

e)

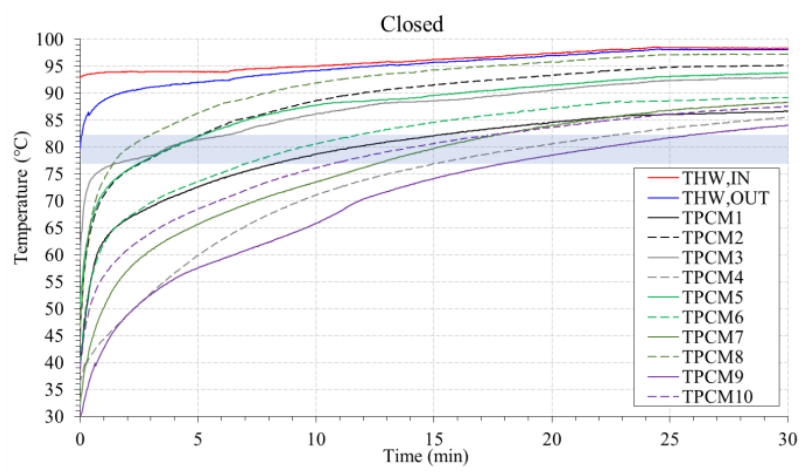

b)

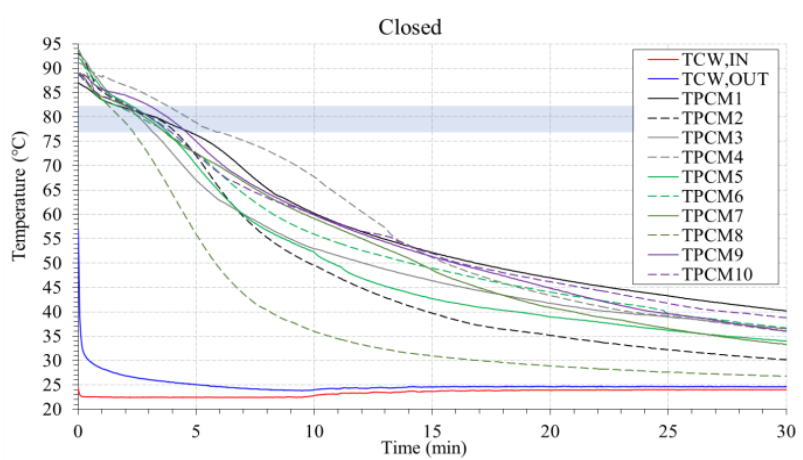

d)

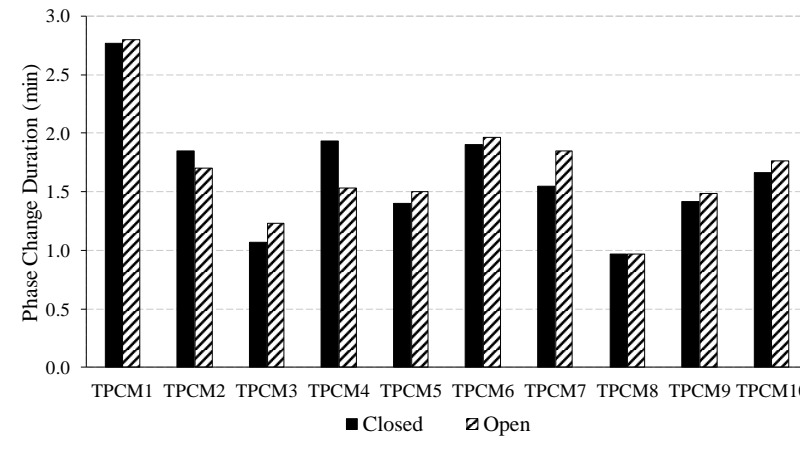

f)

Figure 6. Temperature distribution: a) melting Open mode; b) melting Closed mode; c) solidification Open mode; d) solidification Closed mode. Phase change duration: e) melting; f) solidification

\section{Conclusions}

In the present study, an experimental investigation was carried out to evaluate the effect of Open and Closed operation mode on the heat flux of PCM heat exchanger and melting and solidification time of the PCM. The analysis showed that the heat flux in Open and Closed modes of operation differs very slightly between both melting and solidification processes. Taking into consideration the average PCM temperature, it was observed that phase transition during the melting in the case of Closed mode takes 0.4 minutes shorter compared to the Open mode, the solidification time - 0.1 minutes shorter compared to the Open mode. Analysing phase change duration in different measurement points the same tendency was observed: during melting and solidification the phase transition is shorter in the Closed mode of operation. Thus, it is concluded from the research that the performance of the PCM based heat exchanger can be improved in the Closed mode of operation, i.e. when the PCM is operated under a certain pressure. Possible causes include better thermal contact due to air pressure on PCM, which prevents the formation of the air gaps between PCM and HX, and smoother PCM solidification around the heat transfer surface. It should be noted that in order to evaluate the difference between different operating modes, the heat transfer fluid temperature has to be precisely controlled and the PCM amount should be selected according to the system inertia, which if selected appropriately can improve the resolution of the experiment. 


\section{Disclosure statement}

Authors declare that they have no any competing financial, professional, or personal interests from other parties.

\section{References}

Besagni, G., \& Croci, L. (2019). Experimental study of a pilot-scale fin-and-tube phase change material storage. Applied Thermal Engineering, 160 (April), 114089. https://doi.org/10.1016/j.applthermaleng.2019.114089

Cabeza, L. F., Zsembinszki, G., \& Martín, M. (2020). Evaluation of volume change in phase change materials during their phase transition. Journal of Energy Storage, 28 (September 2019), 101206. https://doi.org/10.1016/j.est.2020.101206

Chiew, J., Chin, C. S., Jia, J., Toh, W. D., \& Gao, Z. (2017). Effects of void spaces in a phase change material based thermal energy storage system. Energy Procedia, 143, 559-565. https://doi.org/10.1016/j.egypro.2017.12.727

Chiew, J., Chin, C. S., Toh, W. D., Gao, Z., \& Jia, J. (2019). Thermal state-of-expansion or melting of phase change material based heat sink for underwater battery power system. Journal of Energy Storage, 26, 100956. https://doi.org/10.1016/j.est.2019.100956

Dallaire, J., \& Gosselin, L. (2016). Various ways to take into account density change in solid-liquid phase change models: Formulation and consequences. International Journal of Heat and Mass Transfer, 103, 672-683. https://doi.org/10.1016/j.ijheatmasstransfer.2016.07.045

Hernández-Cooper, E. M., \& Otero, J. A. (2019). Effects of pressure-induced density changes in the thermal energy absorbed by a micro-encapsulated phase-change material. Molecules, 24(7). https://doi.org/10.3390/molecules24071254

Janghel, D., Saha, S. K., \& Karagadde, S. (2019). Effect of shrinkage void on thermal performance of pure and binary phase change materials based thermal energy storage system: A semi-analytical approach. Applied Thermal Engineering, 167, 114706. https://doi.org/10.1016/j.applthermaleng.2019.114706

Kabbara, M., Groulx, D., \& Joseph, A. (2016). Experimental investigations of a latent heat energy storage unit using finned tubes. Applied Thermal Engineering, 101, 601-611. https://doi.org/10.1016/j.applthermaleng.2015.12.080

Khan, Z., \& Khan, Z. A. (2017). Experimental investigations of charging/melting cycles of paraffin in a novel shell and tube with longitudinal fins based heat storage design solution for domestic and industrial applications. Applied Energy, 206, 1158-1168. https://doi.org/10.1016/j.apenergy.2017.10.043

Li, T. X., Wu, D. L., He, F., \& Wang, R. Z. (2017). Experimental investigation on copper foam/hydrated salt composite phase change material for thermal energy storage. International Journal of Heat and Mass Transfer, 115(Part A), $148-157$. https://doi.org/10.1016/j.ijheatmasstransfer.2017.07.056

Martinelli, M., Bentivoglio, F., Caron-Soupart, A., Couturier, R., Fourmigue, J.-F., \& Marty, P. (2016). Experimental study of a phase change thermal energy storage with copper foam. Applied Thermal Engineering, 101(Suppl. C), 247-261. https://doi.org/10.1016/j.applthermaleng.2016.02.095

Merlin, K., Soto, J., Delaunay, D., \& Traonvouez, L. (2016). Industrial waste heat recovery using an enhanced conductivity latent heat thermal energy storage. Applied Energy, 183, 491-503. https://doi.org/10.1016/j.apenergy.2016.09.007

Pakalka, S., Valančius, K., Čiuprinskas, K., Pum, D., \& Hinteregger, M. (2017). Analysis of possibilities to use phase change materials in heat exchangers-accumulators. In "Environmental Engineering" $10^{\text {th }}$ International Conference. Vilnius Gediminas Technical University. https://doi.org/10.3846/enviro.2017.270

Pakalka, S., Valančius, K., Streckienė, G., \& Ulbikaitė, V. (2018). Fazinio virsmo medžiagos charakteristikų šilumos kaupiklyje skaitinis modeliavimas / Simulation of the phase change materials' characteristics in a thermal energy storage. Mokslas Lietuvos Ateitis / Science - Future of Lithuania, 10. https://doi.org/10.3846/mla.2018.3225

Pakalka, S., Valančius, K., \& Damonskis, M. (2019). Šilumnešio debito įtakos fazinio virsmo medžiagos veikimui tyrimas / Investigation of the influence of mass flow rate on phase change material behaviour. Mokslas - Lietuvos Ateitis / Science Future of Lithuania, 11. https://doi.org/10.3846/mla.2019.10578

Peng, B., Huang, G., Wang, P., Li W., Chang, W., Ma J., \& Li C. (2019). Effects of thermal conductivity and density on phase change materials-based thermal energy storage systems. Energy, 172, 580-591. https://doi.org/10.1016/j.energy.2019.01.147

Righetti, G., Lazzarin, R., Noro, M., \& Mancin, S. (2019). Phase change materials embedded in porous matrices for hybrid thermal energy storages: Experimental results and modeling. International Journal of Refrigeration, 106, 266-277. https://doi.org/10.1016/j.ijrefrig.2019.06.018 